\title{
Biaxial Test of Tubes Using Elastomer
}

Eva Peterkova

Faculty of Mechanical Engineering, Brno University of Technology. Technicka 2896/2, 616 69 Brno. Czech Republic. E-mail: peterkova@fme.vutbr.cz

To obtain the values of material characteristics of tubes such as the strain hardening exponent $\mathbf{n}$ and the strength coefficient $K$ is most frequently used the hydraulic bulge test. The tool and an additional equipment are often complicated and very expensive for this test. This article deals with the question whether it would be possible to obtain the corresponding values $n$ and $K$ by the simple biaxial test of tube using elastomer. To solve this problem, a simple tool was designed and the verification tests were realized for thin-walled tubes from material AISI 321. The results showed that it's not possible to obtain real values $n$ and $K$ by biaxial test of tubes using elastomer. The reason is the elastic forming medium, which complicates the evaluation of these material characteristics, because the elastomer introduces many additional factors into the forming process.

Keywords: Biaxial test, Tube, Elastomer, Strain hardening exponent

\section{Acknowledgement}

This paper was elaborated with the support of specific research Faculty of Mechnical Engineering, Brno University of Technology relating to the grant no. FSI-S-14-2394. Thanks belong to all persons of the Department of metal forming, who helped with the solution of this research.

\section{References}

[1] SONG, W. J., KIM, J., KANG, B. S. (2007). Experimental and analytical evaluation on flow stress of tubular material for tube hydroforming simulation. In: Journal of Materials Processing Technology, Vol. 191, pp. 368371. ISSN 0924-0136.

[2] BORTOT, P., CERETTI, E., GIARDINI, C. (2008). The determination of flow stress of tubular material for hydroforming applications. In: Journal of Materials Processing Technology, Vol. 203, pp. 381-388. ISSN 0924-0136.

[3] HWANG, Y. M., LIN, Y. K., ALTAN, T. (2007). Evaluation of tubular materials by a hydraulic bulge test. In: International Journal of Machine Tools \& Manufacture, Vol. 47, pp. 343-351. ISSN 0890-6955.

[4] STRANO, M., ALTAN, T. (2004). An inverse energy approach to determine the flow stress of tubular materials for hydroforming applications. In: Journal of Materials Processing Technology, Vol. 146, pp. 92-96. ISSN 09240136.

[5] SOKOlOWSKI, T., GERKE, K., AHMETOGLU, M., ALTAN, T. (2000). Evaluation of tube formability and material characteristics: hydraulic bulge testing of tubes. In: Journal of Materials Processing Technology, Vol. 98, pp. 34-40. ISSN 0924-0136.

[6] SONG. W. J., HEO, S. CH., KU, T. W., KIM, J., KANG, B. S. (2010). Evaluation of effect of flow stress characteristics of tubular material on forming limit in tube hydroforming process. In: International Journal of Machine Tools \& Manufacture, Vol. 50, pp. 753-764. ISSN 0890-6955.

[7] KOÇ, M., AUE-U-LAN, Y., ALTAN, T. (2001). On the characteristics of tubular materials for hydroforming experimentation and analysis. In: International Journal of Machine Tools \& Manufacture, Vol. 41, pp. 761-772. ISSN 0890-6955.

[8] LIANFA, Y., CHENG, G. (2008). Determination of stress-strain relationship of tubular material with hydraulic bulge test. In: Thin-Walled Structures, Vol. 46, pp. 147-154. ISSN 0263-8231.

[9] MARCINIAK, Z. (1964). Sheet Metal Forming Theory, pp. 112-195. State publishing of technical literature, Prague.

[10] ČSN EN ISO 604:2004. (2004). Plastics - Determination of compressive properties, pp. 1-20. Czech standards institute, Prague.

[11] SAMEK, R., ČALKOVSKÝ, A. (2000). New relationship defining the values of flow stress, tangent and secant modulus. In: Proceedings of the 8th International Conference Sheet Metal 2000. Ed. 1, pp. 381-386. University of Central England, Birmingham, ISBN 0-95276-643-4. 
[12] BERKOVIČ, I. I., NIKIŠIN, V. E., NIKOLAJEVA, A. M. (1988). Assessment of the contact friction forces effect on a forming process by an elastic medium. In: Kuznečno-štampovočnoe proizvodstvo, No. 4, pp. 15-16.

[13] GIRARD, A. C., Y. J. GRENIER a B. J. MAC DONALD. Numerical simulation of axisymmetric tube bulging using a urethane rod. Journal of Materials Processing Technology. 2006, 172(3), 346-355. DOI: 10.1016/j.jmatprotec.2005.10.012. ISSN 09240136.

[14] THIRUVARUDCHELVAN, S. a F. W. TRAVIS. Tube bulging with a urethane rod. Journal of Materials Processing Technology. 1990, 23(2), 195-209. DOI: 10.1016/0924-0136(90)90157-P. ISSN 09240136.

[15] ŽMINDÁK, M., MEŠKO, J., PELAGIĆ, Z., ZRAK, A. (2014). Finite element analysis of crack growth in pipelines. In: Manufacturing Technology. Vol. 14, No. 1, pp. 116-122. ISSN 1213-2489.

[16] YOU, J. CH., LIN, J. D., XU, D. F., HAO, W. Y. (2016). Contact Analysis of Silicone Rubber Rectangular Ring in the Automatic Tighten Assembly. In: Manufacturing Technology. Vol. 16, No. 3, pp. 648-653. ISSN 12132489.

\section{Paper number: M2016143}

Copyright () 2016. Published by Manufacturing Technology. All rights reserved. 